\title{
Comparative Evaluations of Selected Pigeon Pea (Cajanus cajan) Genotypes for Biomass Yield, Nutrient Composition, and Dry Matter Intake under Diverse Locations of Tropical Africa
}

\author{
Abuye Tulu (D), Mekonnen Diribsa, Gutu Fekede, Worku Temesgen, Wakgari Keba, \\ and Alemayehu Kumsa
}

Oromia Agricultural Research Institute, Bako Agricultural Research Center, P.O. Box 03, Bako, Ethiopia

Correspondence should be addressed to Abuye Tulu; armdilla@gmail.com

Received 19 February 2021; Revised 14 September 2021; Accepted 16 September 2021; Published 23 September 2021

Academic Editor: Mirza Hasanuzzaman

Copyright (c) 2021 Abuye Tulu et al. This is an open access article distributed under the Creative Commons Attribution License, which permits unrestricted use, distribution, and reproduction in any medium, provided the original work is properly cited.

Feeding standards of ruminant livestock could be significantly enhanced through the cultivation of improved quality forages, which are suitable for different agroclimatic conditions in tropical Africa. In this frame, ten pigeon pea (Cajanus cajan) genotypes were evaluated across three locations in western Ethiopia during the 2014 and 2015 cropping seasons using a randomized complete block design with three replications. The study was designed to determine the nutrient composition, in vitro digestibility, and dry matter intake of selected pigeon pea genotypes. The result revealed that the studied quality parameters were significantly influenced by the genotypic and environmental main effects but not their interaction, while forage yield was influenced by both main effects and their interaction. Mean forage yield was greater for Degagsa across all locations followed by Belabas. In vitro organic matter digestibility and ash parameters did not vary among genotypes. However, variations were observed across locations for daily dry matter intake (DMI) and crude protein (CP) with the greatest value received from Degagsa and Belabas. The fiber components of Degagsa and Belabas were less than those of the remaining genotypes. Generally, Degagsa and Belabas had shown a greater forage yield, DMI, and CP content, but less in fiber components, and thus can be cultivated to enhance livestock productivity in western Ethiopia and similar agroecologies of tropical Africa.

\section{Introduction}

The ruminant livestock production system is hindered by inadequacy and low quality of feed. A high level of productivity cannot be obtained since the tropical grasses which are usually fed to this livestock are inherently low in protein [1]. Likewise, the cereal straws and native grass hay commonly used as a roughage feed source for dairy animals in the present study area were observed to contain considerably low $\mathrm{CP}$, in vitro organic matter digestibility, and higher levels of detergent fibers [2]. When fed alone, these characteristics of the feeds lead to a slow rate at which feed particles break down to a size that can leave the rumen and result in low total digestibility of nutrients [3]. This suggests the need for additional protein supplementation for efficient utilization of the basal feed resources and subsequent betterment of livestock production in the country.
Supplementation of low-quality feeds with leguminous forage in ruminant diets can potentially be considered for use to offset limitations associated with low feed quality in systems where livestock are increasingly becoming dependent on low-quality roughages [4]. In this regard, the effective use of leguminous forage crops as an alternative source of protein in livestock feeding has become an urgent research topic globally. A lot of research studies on the introduction and evaluation of leguminous forage species have been performed extensively. Pigeon pea species are one of the potential forage legumes being extensively evaluated under the agroecology of tropical Africa.

In these forage legume evaluation programs, much attention has been given to the evaluation of their biomass yielding potential and environmental adaptation. Information on their nutrient composition and digestibility 
potential, however, is rarely addressed. Getachew et al. and Diriba et al. $[5,6]$ revealed that a database on nutrient composition and nutritional value of promising forages is one of the basic technical inputs required to design strategies for alleviating poor nutrition and optimizing the utilization of available low-quality feed resources. Thus, to properly balance the use of pigeon pea in ruminant nutrition, there is a need for an adequate understanding of the nutrient availability from this forage species. Therefore, keeping in view the scarcity of quality fodder and the necessity of characterizing the nutrient profile of pigeon pea genotypes to identify the most proper genotypes for ruminants, the current study was undertaken with the objectives to evaluate the dry matter intake, nutrient composition, and in vitro digestibility of selected pigeon pea genotypes under the agroclimatic conditions of tropical Africa.

\section{Materials and Methods}

2.1. Study Locations. The experiment was conducted during the years 2014 and 2015 at three locations (Bako, Gute, and Chewaka) located in subhumid areas of western Oromia, Ethiopia. Descriptions of the test locations are indicated in Table 1.

2.2. Experimental Design and Treatments. A total of thirty plots of $4 \times 3 \mathrm{~m}$ were established on 1 June 2014 across locations (Bako, Gute, and Chewaka, Ethiopia). The genotypes tested in the current study were ILRI 16274, ILRI 16277, ILRI 16520, ILRI 16524, ILRI 16526, ILRI 16528, ILRI 16555, ILRI 16527, ILRI 11575, and Tsigab (check). Among the genotypes tested, Tsigab was already registered as a variety and thus used as a standard check for performance comparison against the genotypes evaluated in the present study, whereas genotypes ILRI 16527 and ILRI 11575 (to be referred hereafter as Belabas and Degagsa, respectively) were verified against the check in 2016 and thus registered as a variety. The experiment was set up using a randomized complete block design with three replications. In each plot, seeds of the designated pigeon pea genotype were planted in a row at spacing of $1 \mathrm{~m}$ and $0.5 \mathrm{~m}$ between the row and plants, respectively. Diammonium phosphate (DAP) fertilizer was applied to all plots during plantation at a rate of $100 \mathrm{~kg} \mathrm{ha}^{-1}$.

2.3. Herbage Dry Matter Yield. The two inner rows were manually harvested by hand using a sickle leaving a stubble height of $5 \mathrm{~cm}$ at $50 \%$ flowering stages for herbage dry matter yield estimation. The fresh weight of the cut biomass was measured just after mowing with a suspended field balance. Then, composited samples of 200 g per treatment were taken from each location and experimental year, weighed, and oven-dried at $65^{\circ} \mathrm{C}$ for $72 \mathrm{hrs}$ until a constant weight was obtained to determine the herbage dry matter (DM) content and yield. These subsamples were then ground to pass through a $1 \mathrm{~mm}$ sieve screen size for the chemical analysis of quality traits.
2.4. Chemical Analysis and Calculated Measurements. Nitrogen content was analyzed according to the AOAC984.13 [7] procedure. Crude protein was estimated by multiplying the $N$ value by a factor of 6.25. Neutral detergent fiber (NDF), acid detergent fiber (ADF), and acid detergent lignin (ADL) were analyzed using the procedures of Van Soest et al. [8]. The in vitro organic matter digestibility (IVOMD) was determined using the Tilley and Terry [9] method. Potential daily dry matter intake (DMI) was also calculated as DMI: $1.2 \times$ body weight/NDF\% [10], where body weight is equivalent to an estimated livestock unit metabolic weight of $450 \mathrm{~kg}$.

2.5. Data Analysis. Analysis of variance following the general linear model procedure of SAS [11] version 9.3 was used for data analysis. Herbage DM yield was analyzed for the main effects of the genotype and environment (year $\times$ location) and their interaction with replicate $\times$ year $\times$ location, while quality traits were analyzed for the main effects of the genotype and environment with year as the blocking factor. Means were separated using the least significant difference at a $5 \%$ level of significance.

\section{Results and Discussion}

3.1. Herbage Dry Matter Yield. The result from the analysis of variance for herbage dry matter yield of the 10 pigeon pea genotypes over the three sites is shown in Table 2. Herbage DM yield was significantly affected by the genotype, location, and year with a significant interaction, so data for individual locations in each year are presented. The result revealed that, for the environmental grouping, the lowest mean herbage DM yield was recorded in 2014 at the Bako location, while the higher was received in 2015 at the Chewaka location (Table 2). Concerning the genotypic effect, the lower mean herbage DM yield was observed for ILRIL 16528, while the highest was recorded for Degagsa followed by Belabas, with a mean value of $4.32 \mathrm{t} \mathrm{ha}^{-1}$. For combined analysis, however, the highest mean herbage DM yield $\mathrm{t} \mathrm{ha}^{-1}$ was obtained from Degagsa in 2014, while the lower mean value was recorded from ILRI 16526 in 2014. In agreement with the present study result, significant differences in DM yield have been observed previously among 6 accessions of cowpea (Vigna unguiculata L. Walp.) evaluated for the agroecological difference across five locations in lowlands of southern Ethiopia [12]. Ilknur et al. [13] also reported that a significant variation in DM yield was observed among nine cowpea genotypes tested across two environments.

The herbage DM yield observed in the present study was lower than the finding reported by Debela et al. [14] who studied the forage yield and quality of five pigeon pea genotypes under the agroecology of southwestern Ethiopia. This variation might be attributed to the difference in the genetic potential of the genotypes studied and agroecologies where the studies were carried out. In conformity to the current finding, herbage DM yield ranging from 4.4 to $5 \mathrm{t}$ $\mathrm{ha}^{-1}$ was reported by Alexander et al. [15] who evaluated the 
TABLE 1: Geographical description of the test locations in tropical western Ethiopia.

\begin{tabular}{lccc}
\hline Parameters & & \multicolumn{2}{c}{ Test locations } \\
& Bako & Chewaka & $9^{\circ} 01^{\prime} \mathrm{N}$ \\
\hline Latitude & $9^{\circ} 06^{\prime} \mathrm{N}$ & $09^{\circ} 98285^{\prime} \mathrm{N}$ & $36^{\circ} 40^{\prime} \mathrm{E}$ \\
Longitude & $37^{\circ} 09^{\prime} \mathrm{E}$ & $036^{\circ} 11703^{\prime} \mathrm{E}$ & 1880 \\
Altitude (masl) & 1650 & 1259 & 2067 \\
Average annual rainfall $(\mathrm{mm})$ & 1431 & 1600 & 12.2 \\
Average minimum temperature $\left({ }^{\circ} \mathrm{C}\right)$ & 11.23 & 18 & 27.9 \\
Average maximum temperature $\left({ }^{\circ} \mathrm{C}\right)$ & 31.74 & 32 & Clay loam (60\%), sandy soil (35\%), and clay (5\%) \\
Soil type & Sandy clay & Sandy loam
\end{tabular}

The annual mean rainfall, mean minimum, and maximum temperature for the Chewaka location were reported from Diga district located at a distance of about $15 \mathrm{~km}$.

TABLE 2: Herbage dry matter yield $\left(\mathrm{t} \mathrm{ha}^{-1}\right)$ of the selected ten pigeon pea genotypes tested at three locations in Ethiopia.

\begin{tabular}{|c|c|c|c|c|c|c|c|}
\hline \multirow{2}{*}{ Genotypes } & \multicolumn{3}{|c|}{2014} & \multicolumn{3}{|c|}{2015} & \multirow{2}{*}{ Mean } \\
\hline & Bako & Chewaka & Gute & Bako & Chewaka & Gute & \\
\hline ILRI 16274 & $2.69^{\mathrm{efg}}$ & $4.99^{\mathrm{cd}}$ & $3.57^{\mathrm{bc}}$ & $2.66^{\mathrm{f}}$ & $3.37^{\mathrm{c}}$ & $2.85^{\mathrm{e}}$ & $3.35^{\mathrm{ef}}$ \\
\hline ILRI 16277 & $2.80^{\mathrm{ef}}$ & $4.48^{\mathrm{dc}}$ & $4.62^{\mathrm{b}}$ & $3.22^{\mathrm{de}}$ & $3.58^{\mathrm{c}}$ & $2.93^{\mathrm{e}}$ & $3.61^{\mathrm{e}}$ \\
\hline ILRI 16520 & $2.57^{\mathrm{fg}}$ & $5.27^{\mathrm{bc}}$ & $3.80^{\mathrm{bc}}$ & $2.77^{\mathrm{ef}}$ & $3.27^{\mathrm{c}}$ & $2.78^{\mathrm{e}}$ & $3.41^{\mathrm{ef}}$ \\
\hline ILRI 16524 & $2.56^{\mathrm{fg}}$ & $3.84^{\mathrm{d}}$ & $2.91^{\mathrm{c}}$ & $3.71^{\mathrm{cd}}$ & $3.53^{\mathrm{c}}$ & $2.70^{\mathrm{e}}$ & $3.21^{\mathrm{f}}$ \\
\hline ILRI 16526 & $2.33^{\mathrm{g}}$ & $4.53^{\mathrm{cd}}$ & $3.53^{\mathrm{bc}}$ & $3.60^{\mathrm{cd}}$ & $3.31^{\mathrm{c}}$ & $2.97^{\mathrm{e}}$ & $3.38^{\mathrm{ef}}$ \\
\hline ILRI 16528 & $3.01^{\mathrm{e}}$ & $4.89^{\mathrm{cd}}$ & $2.91^{\mathrm{c}}$ & $2.57^{\mathrm{f}}$ & $2.96^{\mathrm{c}}$ & $2.64^{\mathrm{e}}$ & $3.16^{\mathrm{f}}$ \\
\hline ILRI 16555 & $4.30^{\mathrm{c}}$ & $6.47^{\mathrm{b}}$ & $5.96^{\mathrm{a}}$ & $5.01^{\mathrm{b}}$ & $6.21^{\mathrm{b}}$ & $4.73^{\mathrm{c}}$ & $5.45^{\mathrm{c}}$ \\
\hline Belabas & $5.53^{\mathrm{b}}$ & $8.16^{\mathrm{a}}$ & $6.46^{\mathrm{a}}$ & $5.80^{\mathrm{a}}$ & $6.95^{\mathrm{ab}}$ & $5.51^{\mathrm{b}}$ & $6.40^{\mathrm{b}}$ \\
\hline Degagsa & $6.39^{\mathrm{a}}$ & $9.00^{\mathrm{a}}$ & $7.25^{\mathrm{a}}$ & $6.27^{\mathrm{a}}$ & $7.86^{\mathrm{a}}$ & $6.52^{\mathrm{a}}$ & $7.22^{\mathrm{a}}$ \\
\hline Tsigab & $3.86^{\mathrm{d}}$ & $5.42^{\mathrm{bc}}$ & $3.71^{b c}$ & $3.91^{\mathrm{c}}$ & $3.90^{\mathrm{c}}$ & $3.59^{\mathrm{d}}$ & $4.07^{\mathrm{d}}$ \\
\hline Mean & 3.61 & 5.71 & 4.47 & 3.95 & 4.49 & 3.72 & 4.32 \\
\hline LSD & 0.39 & 1.23 & 1.29 & 0.48 & 1.03 & 0.44 & 0.39 \\
\hline CV (\%) & 6.32 & 12.6 & 16.77 & 7.14 & 13.32 & 6.89 & 13.55 \\
\hline$P$ value & $<0.0001$ & $<0.0001$ & $<0.0001$ & $<0.0001$ & $<0.0001$ & $<0.0001$ & $<0.0001$ \\
\hline
\end{tabular}

Values are the means of three replicates in each year at each location. $P$ values for the main effects of the genotype (G), environment $(\mathrm{E}=$ year $\times$ location), and $\mathrm{G} \times \mathrm{E}$ interaction are $0.0001,0.0001$, and 0.0098 , respectively. ${ }^{\mathrm{a}, \mathrm{b}, \mathrm{c}, \mathrm{d}, \mathrm{e}, \mathrm{f}, \mathrm{g}}$ Means within a row with different superscripts differ significantly $(P<0.05)$. LSD: least significant difference; ILRI: International Livestock Research Institute, Addis Ababa, Ethiopia.

variation in forage yield and quality traits of 200 pigeon pea lines under the agroecology of Patancheru, India.

3.2. Quality Features and Daily Dry Matter Intake. Mean nutrient composition of the ten pigeon pea genotypes tested across three locations is shown in Table 3. Except for ash and IVOMD, the remaining quality parameters were significantly influenced by the main effects of the location, while environmental main effects had shown a significant influence for $\mathrm{CP}$, ash, daily DM intake, and fiber constituents, but not for IVOMD. None of the studied quality traits were influenced as a result of the interaction between the environment and genotypes; thus, combined analysis was employed for studied quality traits. The greatest $\mathrm{CP}$ concentration occurred in Degagsa, followed by Belabas, Tsigab (control), and ILRI 16555, while the remaining genotypes had the least $\mathrm{CP}$ value (Table 3 ). The CP content of all the studied pigeon pea genotypes was higher than the minimum threshold value of $15 \%$ required to support lactation and growth in dairy cows [16], suggesting the adequacy of all the studied genotypes to supplement ruminants based on predominantly low-quality pasture and crop residue $[2,3]$.
The $\mathrm{CP}$ values found in the current study (Table 3) agree with the $\mathrm{CP}$ content of leguminous forage crops reported in various literature studies for selected browse plants [17], Lablab purpureus species [18], and Centrosema species [6], but greater than for some legume plant species derived from Egyptian rangeland reported by Mahmoud et al. [19]. In addition to genetic variability, differences in $\mathrm{CP}$ between this and other studies may be attributed to differences in rainfall, soil fertility, forage harvesting stage, and other climatic conditions in which the studies were carried out.

Except for Degagsa and Belabas, which contained NDF falling within the range of 400 to $460 \mathrm{~g} \mathrm{~kg}^{-1} \mathrm{DM}$ to be rated as having a first-grade quality standard as reported by Kazemi et al. [20], the remaining genotypes conform to the value ranging from 450 to $650 \mathrm{~g} \mathrm{~kg}^{-1} \mathrm{DM}$ (Table 3) to be classified as medium-quality feeds [21]. Irrespective of the remaining genotypes tested in the present study, the ADF content of Degagsa and Belabas genotypes falls within the range of 310 to $400 \mathrm{~g} \mathrm{~kg}^{-1} \mathrm{DM}$, where browse substrate is regarded as having a first-grade quality standard and is expected to be digestible without negatively influencing the bioavailability of CP [20]. The mean ADL content of the ten pigeon pea genotypes across the study location (Table 3 ) is nearly comparable to the results reported by Hunegnaw and 
TABLE 3: Combined analysis of variance for quality parameters and daily dry matter intake of the selected ten pigeon pea genotypes tested across three environments (locations) in Ethiopia.

\begin{tabular}{|c|c|c|c|c|c|c|c|}
\hline Genotypes & $\mathrm{CP}$ & Ash & NDF & $\mathrm{ADF}$ & $\mathrm{ADL}$ & IVOMD & DMI \\
\hline ILRI 16274 & $191.5^{\mathrm{cd}}$ & 97.7 & $573.3^{\mathrm{a}}$ & $415.3^{\mathrm{a}}$ & $189^{\mathrm{b}}$ & 519.4 & $9.5^{\mathrm{b}}$ \\
\hline ILRI 16277 & $189.8^{\mathrm{d}}$ & 101.1 & $585.3^{\mathrm{a}}$ & $392.2^{\mathrm{a}}$ & $195.3^{\mathrm{ab}}$ & 519.3 & $10.3^{\mathrm{b}}$ \\
\hline ILRI 16520 & $200.4^{\mathrm{bcd}}$ & 92.0 & $549.9^{\mathrm{ab}}$ & $403.1^{\mathrm{a}}$ & $189.8^{\mathrm{b}}$ & 516.7 & $10.5^{\mathrm{b}}$ \\
\hline ILRI 16524 & $198.9^{\mathrm{bcd}}$ & 94.9 & $550.7^{\mathrm{ab}}$ & $409.1^{\mathrm{a}}$ & $194.6^{\mathrm{ab}}$ & 515.9 & $9.9^{\mathrm{b}}$ \\
\hline ILRI 16526 & $200.3^{\mathrm{bcd}}$ & 99.6 & $578.9^{\mathrm{a}}$ & $408.6^{\mathrm{a}}$ & $203.1^{\mathrm{ab}}$ & 518.8 & $9.3^{\mathrm{b}}$ \\
\hline ILRI 16528 & $198.0^{\mathrm{bcd}}$ & 97.1 & $582.8^{\mathrm{a}}$ & $407.5^{\mathrm{a}}$ & $200.3^{\mathrm{ab}}$ & 516.5 & $9.3^{\mathrm{b}}$ \\
\hline ILRI 16555 & $205.3^{\mathrm{b}}$ & 99.1 & $518.7^{\mathrm{b}}$ & $406.7^{\mathrm{a}}$ & $207.1^{\mathrm{a}}$ & 522.9 & $10.5^{\mathrm{b}}$ \\
\hline Belabas & $201.6^{\mathrm{bc}}$ & 98.7 & $440.7^{\mathrm{c}}$ & $326.0^{\mathrm{b}}$ & $164.6^{\mathrm{c}}$ & 519.0 & $12.6^{\mathrm{a}}$ \\
\hline Degagsa & $220.8^{\mathrm{a}}$ & 93.5 & $437.5^{\mathrm{c}}$ & $322.2^{\mathrm{b}}$ & $170.1^{c}$ & 525.7 & $12.6^{\mathrm{a}}$ \\
\hline Tsigab & $203.2^{\mathrm{b}}$ & 94.5 & $506.9^{\mathrm{b}}$ & $391.9^{\mathrm{a}}$ & $194.3^{\mathrm{ab}}$ & 520.2 & $10.7^{\mathrm{b}}$ \\
\hline Mean & 201 & 96.8 & 532.5 & 388.3 & 190.8 & 519.5 & 10.5 \\
\hline LSD & 11.3 & 0.96 & 47.9 & 24.1 & 1.5 & 9.9 & 1.63 \\
\hline $\mathrm{CV}$ & 5.96 & 10.53 & 9.53 & 6.58 & 8.34 & 2.03 & 16.43 \\
\hline \multicolumn{8}{|c|}{$P$ values } \\
\hline Genotype (G) & 0.0002 & 0.5201 & $<0.0001$ & $<0.00011$ & $<0.0001$ & 0.6767 & 0.0002 \\
\hline Environment (E) & $<0.0001$ & 0.0192 & 0.0043 & 0.0001 & $<0.0001$ & 0.6867 & 0.0833 \\
\hline $\mathrm{G} * \mathrm{E}$ & 0.9772 & 0.1045 & 0.2287 & 0.5559 & 0.1912 & 0.9943 & 0.5144 \\
\hline
\end{tabular}

Values are the means of two years as replicates. ${ }^{\text {a,b,c,d }}$ Means within a row with different superscripts differ significantly $(P<0.05)$. CP: crude protein; NDF: neutral detergent fiber; ADF: acid detergent fiber; ADL: acid detergent lignin; IVOMD: in vitro organic matter digestibility; DMI: dry matter intake; LSD: least significant difference; CV: coefficient of variation; ILRI: International Livestock Research Institute, Addis Ababa, Ethiopia.

Berhan [22] and Netsanet and Yonatan [23], but lower than the findings reported by Solomon et al. [24].

Maximum daily dry matter intake (DMI) is a very important factor in ensuring the release of adequate nutrients for maintenance and production. Considerable variations in DMI were observed among the pigeon pea genotypes studied in the current study. The value for DMI was higher for Degagsa and Belabas over the remaining genotypes, which might be most probably related to their lower fiber content leading to a fast rate of passage through the rumen and enhanced the ability of ruminants to consume sufficient forage to meet nutrient requirements [25]. Similar findings were also reported by Hilda et al. [17], reporting that daily dry matter intake for three browse species ( $M$. oleifera, L. leucocephala, and M. azedarach) was high because of the low neutral and acid detergent fiber content.

\section{Conclusion}

The present study demonstrated that a considerable variation among the pigeon pea genotypes tested across three locations was observed for herbage dry matter yield and most of the studied forage quality traits. This variation indicates the potential for selecting superior pigeon pea genotypes to be used as supplements to low-quality feed resources. In general, taking into consideration the forage yield, daily dry matter intake potential, and most of the nutrient composition, it was observed that genotypes Degagsa and Belabas outperformed the rest of the candidate genotypes and thus were recommended for wider cultivation in the study area and similar tropical agroecologies. Thus, future studies should focus on evaluating the performance of ruminants fed on the forage produced by superior-performing, broadly adapted genotypes.

\section{Data Availability}

The data supporting the findings of this study are available from the corresponding author upon request.

\section{Conflicts of Interest}

The authors declare that there are no conflicts of interest.

\section{Acknowledgments}

The authors would like to thank the animal feed research team technical staff of Bako Agricultural Research Center for their assistance in data collection and facilitating routine field management activities. Oromia Agricultural Research Institute is also highly acknowledged for funding this research work.

\section{References}

[1] A. Nurfeta, "Digestibility and nitrogen utilization in sheep fed enset (Ensete ventricosum) pseudostem or corm and graded levels of Desmodium intortum hay to wheat straw-based diets," Journal of Animal Physiology and Animal Nutrition, vol. 94, no. 6, pp. 773-779, 2010.

[2] G. Diriba, H. Mekonnen, M. Ashenafi, and T. Adugna, "Nutritive value of selected browse and herbaceous forage legumes adapted to medium altitude sub-humid areas of western Oromia, Ethiopia," Global Veterinaria, vol. 11, pp. 809-816, 2013.

[3] P. McDonald, R. A. Edwards, J. F. D. Greenhalgh, and C. A. Morgan, Animal Nutrition, Prentice-Hall, Hoboken, NJ, USA, 6th edition, 2002.

[4] B. L. Maass, M. R. Knox, S. C. Venkatesha, T. T. Angessa, S. Ramme, and B. C. Pengelly, "Lablab purpureus-a crop lost for Africa?" Tropical Plant Biology, vol. 3, no. 3, pp. 123-135, 2010. 
[5] G. Getachew, P. H. Robinson, E. J. Depeters, and S. J. Taylor, "Relationships between chemical composition, dry matter degradation and in vitro gas production of several ruminant feeds," Animal Feed Science and Technology, vol. 111, no. 1-4, pp. 57-71, 2004.

[6] G. Diriba, H. Mekonnen, M. Ashenafi, and T. Adugna, "Herbage yield and quality of selected accessions of Centrosema species grown under sub-humid climatic conditions of western Oromia, Ethiopia," Global Veterinaria, vol. 11, pp. 735-741, 2013.

[7] AOAC (Association of Official Analytic Chemists), Official Methods of Analysis of AOAC International, AOAC International, Gaithersburg, MD, U.S.A, 18th edition, 2005.

[8] P. J. Van Soest, J. B. Robertson, and B. A. Lewis, "Methods for dietary fiber, neutral detergent fiber, and nonstarch polysaccharides in relation to animal nutrition," Journal of Dairy Science, vol. 74, no. 10, pp. 3583-3597, 1991.

[9] J. M. A. Tilley and R. A. Terry, "A two-stage technique for the in vitro digestion of forage crops," Grass and Forage Science, vol. 18, no. 2, pp. 104-111, 1963.

[10] D. R. Mertens, "Physical and chemical characteristics of fiber affecting dairy cow performance," in Proceeding of the 2002 Cornell Nutrition Conference for Feed Manufacture, Cornell University, East Syracuse, NY, USA, 2002.

[11] SAS (Statistical Analysis System), User's Guide: Version 9.3, SAS Institute, Inc., Cary, NC, USA, 2007.

[12] T. T. Tessema, "Evaluation of forage type cowpea (Vigna unguiculata L. Walp.) accessions for dry matter yield in the lowland of southern Ethiopia," Forage Research, vol. 44, pp. 74-80, 2018.

[13] A. Ilknur, M. Hanife, B. Ugur, A. Zeki, and O. A. Ozlem, "Forage potential of cowpea (Vigna unguiculata L. WALP)," Turkish Journal of Field Crops, vol. 17, pp. 135-138, 2012.

[14] H. Debela, K. Sintayehu, and B. Berako, "Evaluations of Pigeon pea (Cajanus cajan) for dry matter yield and chemical composition on the station of Jinka agricultural research center, south Omo, south-western Ethiopia," AmericanEurasian Journal of Agricultural \& Environmental Sciences, vol. 20, pp. 129-136, 2020.

[15] G. Alexander, D. Ravi, C. R. Reddy et al., "Forage yield and quality in pigeon pea germplasm lines," Journal of SAT Agricultural Research, vol. 3, pp. 1-3, 2007.

[16] S. Ratnawaty, H. Soebarinoto, and S. Chuzaemi, "Production and nutritive value of shrub legumes in west timor, east nusa tenggara province Indonesia," Journal of Agricultural Science and Technology, vol. 3, pp. 349-355, 2013.

[17] K. M. Hilda, N. S. Amenda, E. R. Khuliso, and N. Lindani, "Chemical composition, in vitro ruminal dry matter degradability, and dry matter intake of some selected browse plants," Cogent Food and Agriculture, vol. 5, Article ID 1587811, 2019.

[18] T. Abuye, T. Werku, D. Mekonnen, K. Wakgari, F. Gutu, and K. Alemayehu, "Herbage yield potential, crude protein yield, and feeding value of selected Lablab purpureus cultivars grown under the sub-humid climatic conditions of western Oromia, Ethiopia," International Journal of Applied Agricultural Research, vol. 6, pp. 93-100, 2018.

[19] A. E. M. Mahmoud, M. S. Abbas, A. Cieslak, and M. Szumacher-Strabel, "Evaluation of chemical composition and in vitro dry matter and organic matter digestibility of some forage plant species derived from Egyptian rangelands," The Journal of Animal and Plant Sciences, vol. 27, pp. 15731581, 2017.
[20] M. Kazemi, A. M. Tahmasbi, A. A. Naserian, R. Valizadeh, and M. M. Moheghi, "Potential nutritive value of some forage species used as ruminant feed in Iran," African Journal of Biotechnology, vol. 11, pp. 12110-12117, 2012.

[21] G. P. Singh and S. J. Oosting, A Model for Describing the Energy Value of Straws, FAO, Rome, Italy, 1992.

[22] A. Hunegnaw and T. Berhan, "Effects of supplementation with pigeon pea (Cajanus cajan), cowpea (Vigna unguiculata), and lablab (Lablab purpureus) on feed intake, body weight gain, and carcass characteristics in wollo sheep fed grass hay," International Journal of Advanced Research in Biological Science, vol. 3, pp. 280-295, 2016.

[23] B. Netsanet and K. Yonatan, "Participatory evaluation of dualpurpose pigeon pea (Cajanus cajan) leaves for sheep feeding," Journal of Biology, Agriculture, and Healthcare, vol. 5, pp. 224-230, 2015.

[24] T. Solomon, B. Wondimagegne, A. Desalegn, Z. Asress, B. Niguse, and W. Misganawu, "Evaluation of the effect of pigeon pea dried leave supplementation on feed intake and live weight change on local sheep breeds in eastern Amhara, Ethiopia," International Journal of Advanced Research in Biological Sciences, vol. 3, pp. 81-85, 2016.

[25] D. P. Poppi, "Nutritional constraints for grazing animals and the importance of selective grazing behaviour," in Grassland Productivity and Ecosystem Services, pp. 19-26, CABI, Wallingford, UK, 2011. 